\title{
The magic world of whiskey microbiota
}

\author{
Ajda PRISTAVEC ${ }^{1,2}$, Simon KOREN ${ }^{3}$, Barbara JERŠEK ${ }^{4}$, Anja VERONOVSKI ${ }^{3}$, Leon KOROŠEC ${ }^{3}$, Miha \\ KOVAČ $^{3}$, Minka KOVAČ ${ }^{3}$, Nataša TOPLAK ${ }^{3}$
}

Received May 26, 2020; accepted October 03, 2020.

Delo je prispelo 26. maj 2020, sprejeto 03. oktober 2020.

The magic world of whiskey microbiota

Abstract: Modern metagenomics techniques in combination with next generation sequencing are increasingly used for research of numerous environments inhabited by diverse microbiota. In the present study we focused on a rather unusual environment for their growth, a forgotten bottle of blended Scotch whiskey. Whiskey is a world-known popular spirit, traditionally produced in a series of steps comprising malting of barley, fermenting the malt to an alcoholic wort, distilling and at least 3-year long maturation in oak casks, followed by filtration. In the process, notably in the fermentation, microorganisms play a crucial role. However, we were primarily interested in potential microbiological and chemical changes that might have taken place over the years while the half-empty whiskey bottle was left open. We found that only a very low number of aerobic mesophilic bacteria survived in it while the ethanol content decreased from $40 \%$ to approximately $30 \%$. Interestingly, the metagenomics analysis showed there was a large and diverse microbial community present in the forgotten whiskey. Among the most abundant microorganisms were members of human commensal microbiota, some potentially disease-causing and also food spoiling bacteria, in particular genus Pseudomonas. Surprisingly, we even found a non-negligible number of typically environmental bacterial species.

Key words: whiskey; metagenomics; bacteria
Čarobni svet mikrobiote viskija

Izvleček: Raziskave raznovrstnosti mikrobiote številnih okolij so vse pogosteje izvedene s kombiniranjem naslednje generacije sekvenciranja in metagenomskih metod. V naši študiji smo se osredotočili na nenavadno okolje za rast mikroorganizmov, in sicer pozabljeno steklenico Scotch viskija. Viski je svetovno poznana in priljubljena žgana pijača, ki je tradicionalno proizvedena $\mathrm{v}$ več korakih od pridobivanja ječmenovega slada, fermentacije $\mathrm{v}$ alkoholno sladico in destilacije, ki ji sledi vsaj 3 leta trajajoče staranje $\mathrm{v}$ hrastovih sodih in končna filtracija. $\mathrm{Za}$ fermentacijo so mikroorganizmi nujno potrebni. $\mathrm{V}$ naši raziskavi so nas predvsem zanimale potencialne mikrobiološke in kemijske spremembe, ki so se zgodite tekom let, ko je bila pozabljena, pol prazna steklenica odprta. Ugotovili smo, da je preživelo le zelo malo števila aerobnih mezofilnih bakterij. Koncentracija etanola se je zmanjšala iz začetnih $40 \%$ na približno 30 \%. Metagenomska analiza je razkrila veliko in raznovrstno mikrobno skupnost, ki je živela v pozabljenem viskiju. Med najpogostejšimi mikroorganizmi so bili člani običajne človeške mikrobiote, nekaj potencialno patogenih bakterij kot tudi kvarljivcev hrane, na primer bakterije rodu Pseudomonas. Presenetljivo smo potrdili prisotnost tudi nezanemarljivega število tipično okoljskih vrst.

Ključne besede: viski; metagenomika; bakterije

\footnotetext{
Université catholique de Louvain, Place de l'Université, Ottignies-Louvain-la-Neuve, Belgium

2 Corresponding author, e-mail: ajda.pristavec@student.uclouvain.be

3 Omega d.o.o., Ljubljana, Slovenia

4 University of Ljubljana, Biotechnical Faculty, Department of Food Science and Technology, Slovenia
} 


\section{INTRODUCTION}

Microorganisms are extraordinarily diverse and well-conserved living beings that can be found in virtually any habitat on the Earth, regardless of how hostile it may be. Recent advances of biomolecular techniques such as next generation sequencing (NGS) have made it possible to gain an important insight in microbial genomes or their specific regions, especially coupled with metagenomics studies. Together with Fourier-transform infrared spectroscopy (FTIR), we can use them to closely inspect the diversity of bacteria and the composition of the medium they live in.

Metagenomics is an analysis of genetic information from a microbial sample of a specific environment rather than from identical cells cultured in a dish (Laudadio et al., 2019). These sorts of studies are therefore particularly advantageous for the characterisation of groups of microorganisms that cannot be isolated, yet there might be thousands of different species of bacteria in a sample, of which many potentially closely related. There are different NGS techniques on which metagenomics can rely, two primaries being amplicon based and shotgun (Tessler et al., 2017). In the former, a specific region of genome such as 16S rRNA gene sequence is targeted, whereas in the later regions of randomly digested DNA are sequenced (Laudadio et al., 2019). Each of the techniques has its own advantages and disadvantages. Recently, Tessler et al. (2017) have compared the two strategies in a large-scale study of microbial diversity and have shown that the 16S rRNA amplicon approach was superior in both phyla and family identification despite the fact that shotgun strategy produces over a hundred times more of reads. Furthermore, standard analytical FTIR spectroscopy method combined with Attenuated total reflection (ATR), or ATR-FTIR technique, can be used to study different organic materials from liquid to solid samples and can give us qualitative as well as quantitative data about matrices such as whiskey.

The central aim of the present study was to take advantage of such metagenomics studies to characterise a potential microbial community in a forgotten bottle of blended Scotch whiskey. Whiskey is a popular mature spirit drink with a long history dating back to the $15^{\text {th }}$ century, originating from Scotland. It is traditionally produced in a lengthy process which consists of malting of barley, fermenting the malt or some other grain to an alcoholic wort and of distilling, followed by at least 3-year long maturation in oak casks and filtration. Before bottling, whiskey is diluted by water to the desired alcohol concentration and to enhance its rich aroma (Karlsson \& Friedman, 2017). For the fermentation step in the whiskey production, lactic acid bacterial community is of a great importance. The fact that the wort is not boiled makes it possible for the bacteria to survive and participate in the mixed yeast-bacteria fermentation (Makanjuola et al., 1992). At first, bacterial growth is heavily suppressed by the growth of the yeast, then the number of lactic acid bacteria (LAB) rises exponentially in an intermediate phase characterised by heterofermentative Lactobacillus such as Lb. fermentum Beijerinck, 1901 (van Beek \& Priest, 2003), and is finally followed by a stationary phase where lactic acid continues to accumulate due to activity of mostly homofermentative bacteria such as Lb. casei (Orla-Jensen, 1916) Hansen \& Lessel, 1971 or Lb. paracasei Collins et al., 1989 (van Beek \& Priest, 2002). The heterofermentative and homofermentative Lactobacillus flora was reported to comprise strains of $L b$. fermentum, Lb. paracasei, Lb. brevis (Orla-Jensen, 1919) Bergey et al., 1934 and other more rarely detected Lactobacillus (Simpson et al., 2001). However, microorganisms can be also responsible for spoilage of an alcoholic beverage. For example, in brewing, Gram-negative bacteria such as acetic acid bacteria, Zymomonas and Enterobacteriaceae are some of the common beer spoilers that require monitoring in the process (Paradh, 2015). Furthermore, a recent study has shown that Staphylococcus xylosus Schleifer \& Kloos, 1975 makes the beer turbid and produces organic acids and biogenic amines, which alter the taste of the drink (Yu et al., 2019). Nonetheless, the spoilers of whiskey have not yet been described.

Our studied sample was an abandoned half-empty $70 \mathrm{cl}$ bottle of blended Scotch whiskey with $40.0 \%$ ethanol content, which was matured for at least 12 years before put on sale. This Scotch whiskey was left open for a few years at the room temperature and a noticeable cloudy sediment had formed in it over time. From the microbiological standpoint whiskey appears to be far from a favourable medium for the growth of microorganisms, which intrigued us to take a closer look into biochemical alterations of the whiskey, in particular the microbial communities that might have sprouted in the bottle over the years. For this end, various approaches from standard analytical techniques such as ATR - FTIR spectroscopy, to microbiology and modern genetics were combined.

\section{MATERIAL AND METHODS}

\subsection{MATERIAL}

In our study the original sample was a half-empty70 $\mathrm{cl}$ bottle of blended Scotch whiskey. The bottle was originally marked as 12 years matured whiskey with 40 $\%$ of ethanol contents. The bottle was left open for a few 
years at the room temperature. Over the time a noticeable cloudy sediment had formed at the bottom. In our study we used this turbid part of the whiskey.

\subsection{METHODS}

\subsubsection{ATR - FTIR spectroscopy}

ATR - FTIR instrument Spectrum 100 (PerkinElmer) was used for determination of ethanol concentration in the whiskey sample in the spectral region $4000-450 \mathrm{~cm}^{-1}$, using $4 \mathrm{~cm}^{-1}$ resolution and 4 scans. First mixtures of water and absolute ethanol (purity $\geq 99.8 \%$, Sigma - Aldrich) with known ethanol concentrations were prepared and then IR spectra were collected. By increasing ethanol concentration in reference samples $(10 \%, 20 \%, 30 \%, 40 \%, 50 \%, 100 \%)$ broad peak in the range of $3000-3500 \mathrm{~cm}^{-1}$ decreases and peaks between 2850 and $3000 \mathrm{~cm}^{-1}$, at $1045 \mathrm{~cm}^{-1}$ and at $1087 \mathrm{~cm}^{-1}$ increase. Ethanol concentration in whiskey could be determined by comparison with other FTIR spectra or calculated using Spectrum Quant program (PerkinElmer).

\subsubsection{Culturing of bacteria}

Sample of the turbid part of the whiskey was analysed for aerobic mesophilic bacteria and LABwith plate count method using appropriate medium and incubation conditions. Plate Count Agar (PCA, Oxoid CM0325, Hampshire, England) was used for aerobic mesophilic bacteria and De Man, Rugosa, Sharpe medium (MRSc, Oxoid CM0361) with cycloheximide (Sigma Aldrich, 6681-9, St. Louis, MO, USA; $100 \mathrm{mg} \mathrm{l}^{-1}$ ) for LAB. Samples in aliquots of $1 \mathrm{ml}$ were poured and mixed with media and agar plates were incubated for up to 10 days at $30^{\circ} \mathrm{C}$ in normal atmosphere for aerobic mesophilic bacteria and in in anaerobic atmosphere in jar obtaining with anaerobic atmosphere generation bag (Sigma Aldrich, 68061) for LAB. After incubation the number of colonies was counted, and results were expressed as average number of colony forming unit (CFU) per $\mathrm{ml}$ of sample (CFU/ $\mathrm{ml})$.

\subsubsection{Extraction of DNA and quantification}

DNA was extracted using PrepMan Ultra Sample Preparation Reagent following the manufacturer's protocol. $1 \mathrm{ml}$ of the turbid part of the whiskey was first centrifuged for $3 \mathrm{~min}(3,000 \mathrm{~g})$ and the supernatant was removed from the pellet. After DNA extraction the con- centration was measured with Qubit v4 and Qubit dsDNA High-Sensitivity (HS) kit (all Thermo Fisher Scientific).

\subsubsection{S rRNA PCR amplification, Ion Torrent li- brary preparation and sequencing}

The seven hypervariable regions of $16 \mathrm{~S}$ rRNA gene of bacteria were amplified in multiplex PCR reaction using the Ion $16 \mathrm{~S}^{\mathrm{m}}$ Metagenomics Kit. NGS library was prepared using Ion Plus Fragment Library Kit (Thermo Fisher Scientific), following the manufacturer instructions. The amount and size distribution of the prepared library fragments were determined with the Labchip GX microfluidic capillary electrophoresis (PerkinElmer). Emulsion PCR and the enrichment steps were carried out using Ion PGM Hi-Q View OT2 Kit, as described by the manufacturer. Library templates were sequenced with on PGM Hi-Q View Sequencing Kit using an Ion 318 chip with the Ion Torrent PGM instrument (all Thermo Fisher Scientific). Signal processing and base calling were performed with the Torrent Suite software version 5.12.

\subsubsection{Bioinformatics analysis}

Bioinformatics analysis was done with cloud-based software Ion Reporter 5.12 (Thermo Fisher Scientific). Only complete reads covering entire amplicons from primer to primer were used in the analysis. To avoid an artificial increase in sequencing diversity arising from random sequencing errors, only reads with 10 or more copies were used in the analysis. The reads which met all the criteria for the analysis were mapped to both the curated open-source Greengenes v13.5 database and the validated commercial MicroSEQ ${ }^{\circ} 16 S$ Reference Library v2013.1 (Thermo Fisher Scientific). Percentage identity cut-off values of $97 \%$ and $99 \%$ were used to assign genera and species, respectively.

\section{RESULTS}

\subsection{FTIR ANALYSIS}

Ethanol concentration in whiskey was determined by comparison with other FTIR spectra or calculated using Spectrum Quant software. By observing peaks from FTIR spectra, it can be concluded, that ethanol concentration in whiskey sample is around $30 \%$ (Figure 1 and Figure 2). However, using Spectrum Quant software, 


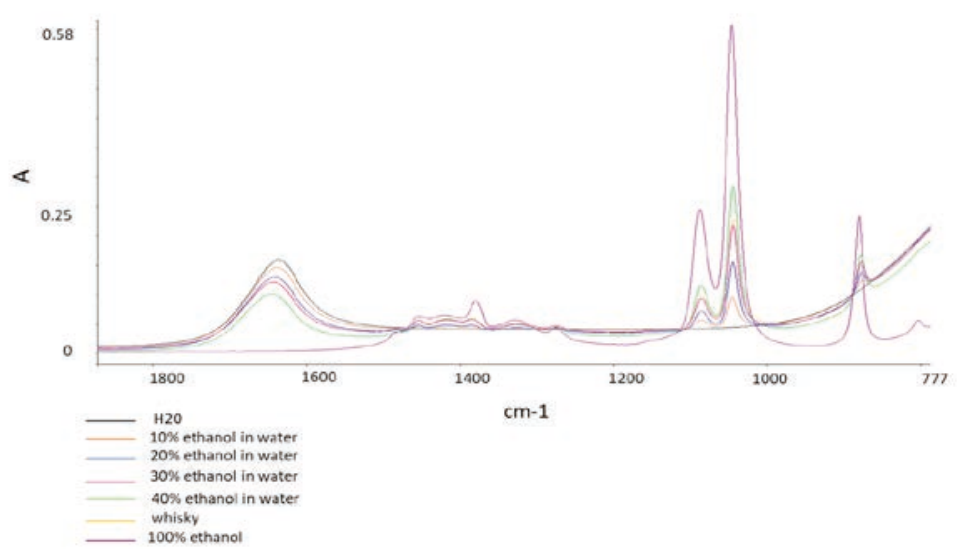

Figure 1: FTIR spectra of pure water, $100 \%$ ethanol, mixtures of ethanol and water (10\%, $20 \%, 30 \%$ and $40 \%)$ and whiskey sample in the range $1800-770 \mathrm{~cm}^{-1}$.



Figure 2: FTIR spectra of pure water, $100 \%$ ethanol, mixtures of ethanol and water $(10 \%, 20 \%, 30 \%$ and $40 \%)$ and whiskey sample in the range $3800-2600 \mathrm{~cm}^{-1}$.

where Beer's Law algorithm was used, calculated value of ethanol concentration in tested whiskey is $30.1 \%$.

\subsection{CULTURING OF VIABLE BACTERIA}

The number of viable bacteria in whiskey was as expected very low, as the average number of aerobic mesophilic bacteria was $45 \pm 10 \mathrm{CFU} \mathrm{ml}^{-1}$ (Gram-positive cocci, and Gram-negative rods), and LAB were not found $\left(<10 \mathrm{CFU} \mathrm{ml}^{-1}\right)$.

\subsection{S rRNA ANALYSIS}

In total, 212,571 reads were obtained after the default filtering and quality trimming in Torrent Suite Software.
Of those, 186,267 reads covered the entire amplicon and were included in further analysis. After discarding reads with less than 10 copies, 92,554 were included in the mapping pipeline. 92,101 reads mapped to at least one of the databases, with only 453 reads remaining unmapped.

Surprisingly, mapping revealed a diverse bacterial community in the sample. In total, 142 bacterial families, 149 genera and 159 species could be mapped unambiguously (Figure 3A and Figure 3B).

More precise results show that Staphylococcus was the most abundant genus in the sample (21.6\% of mapped reads), followed by Anaerococcus (6.2\%), Methylobacterium (5.9 \%) and Streptococcus (5.2 \%). Family distribution was more even, with Staphylococcaceae (14.1\%), Sphingomonadaceae (9.3\%), Enterobacteriaceae (9.0\%) and Comamonadaceae $(6.9 \%)$ representing the four most abundant operational taxonomic units (OTUs) at 


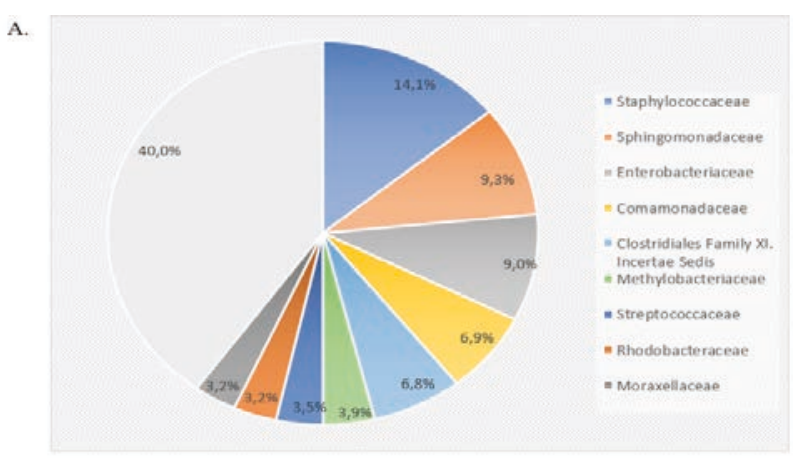

B.

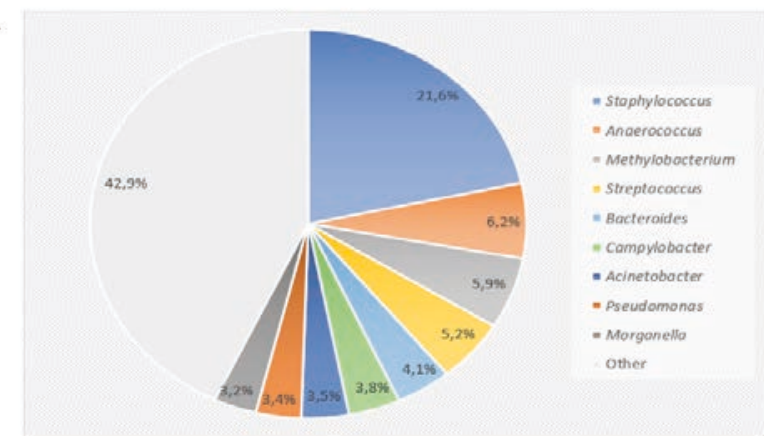

Figure 3: Distribution of (A) families a (B) genera unambiguously detected in the whiskey sample at relative abundances of $3 \%$ or higher

this level. At genus and family level, $42.9 \%$ and $40.0 \%$ of reads mapped to OTUs with relative abundance lower than $3 \%$, which again demonstrates the high diversity of the population. Bacteroides fragilis (Veillon \& Zuber, 1898) Castellani \& Chalmers, 1919, Campylobacter ureolyticus (Jackson \& Goodman, 1978) Vandamme et al, 2010, Anaerococcus vaginalis (Li et al., 1992) Ezaki et al., 2001, Morganella morganii (Winslow et al., 1919) Fulton, 1943, Anaerococcus octavius Murdoch et al., 1997) Ezaki et al., 2001 and Finegoldia magna (Prevot, 1933) Murdoch \& Shah, 2000 were the most abundant species detected. This does not match data from higher taxonomic units but is expected for $16 \mathrm{~S}$ metagenomic analysis. In contrast to common strategies that focus only on one or two regions (V3, V4), our approach covered sequencing of 7 variable $16 \mathrm{~S}$ regions, to ensure as much discriminatory power as possible and economically feasible. Nevertheless, for many OTUs, similarities in sequences of $16 \mathrm{~S}$ rRNA genes for many species are still so high, that it is impossible to distinguish them at the level of species. The most abundant genus Staphylococcus represents such example in our analysis.

\section{DISCUSSION}

The abandoned bottle of Scotch whiskey might seem as a rather hostile medium for the growth of microorganisms, yet our metagenomics analysis suggests there was a large community present in it. Even though the ethanol content of the whiskey decreased from $40 \%$ to $30.1 \%$, diverse species of bacteria had proliferated in it before dying off. Using the cut-off of at least 10 reads, we identified around 160 different species from roughly 150 genera in our whiskey sample. The highest number of reads was recorded for the family of Gram-positive bacteria Staphylococcocae, all of them from genus Staphylococcus. The most abundantly represented species was Staph. Epidermidis (Winslow \& Winslow, 1908) Evans, 1916 which is universally present on human skin and mucosa but can also act as opportunistic pathogen (Coates et al., 2014). Taxonomic composition analysis also revealed very high number of reads for exceptionally large family of Gramnegative bacteria Enterobacteriaceae, which comprises some potentially disease-causing genera such as Shigella, Salmonella, Klebsiella and Escherichia (Brenner et al., 2005).

Amongst the most commonly detected species in the whiskey sample were predominantly commensal organisms which inhabit human alimentary tract or colonise our skin and mucous membranes, some being potentially pathogenic. For instance, the most abundantly represented species Bacteroides fragilis are obligate anaerobic Gram-negative bacteria that are a normal part of 
human intestinal microbiota, yet become pathogenic by endotoxin secretion when the mucosal barrier is disrupted (Elsaghir \& Reddivari, 2020). Similarly, a facultativeanaerobic member of Enterobactericeae family, Morganella morganii is a common member of human intestinal tract flora, but can also act as opportunistic pathogen causing wound and urinary tract infections (Liu et al., 2016). Another frequently detected Gram-negative anaerobic species is Campylobacter ureolyticus, which has been identified as gastrointestinal pathogen, causing Campylobacter-related gastroenteritis (O'Donovan et al., 2014). Furthermore, also aerobic Gram-positive bacteria such as those from genus Corynebacterium were highly represented in the whiskey sample, in particular Corynebacterium striatum (Chester, 1901) Eberson, 1918. This species commonly colonises skin and mucous membranes, but has also been identified as an emerging pathogen causing amongst other also bone and joints infections (Noussair et al., 2019).

On the other hand, food spoilers were not as abundantly represented in the microbial community of our abandoned bottle. Remenant et al. (2015) described LAB and genera Clostridium, Serratia, Hafnia, and Pseudomonas as the main known food spoilers. One important example highly present in our whiskey is genus Pseudomonas, which largely contributes to the food spoilage process. Pseudomonas comprise thermotolerant spoilage microorganisms that cause off-flavour release, reduction of shelf-life and quality of dairy and meat products, discoloration of dairy products and browning of vegetables, along with biofilm formation on chilled foods (Quintieri et al., 2019). Regarding LAB, only very low number of reads were recorded for Lactococcus lactis (Lister, 1873) Schleifer et al., 1986 and even fewer for Lactobacillus iners Falsen et al., 1999, but we also recorded presence of Enterococcus faecalis (Andrewes \& Horder, 1906) Schleifer \& Kilpper-Balz, 1984 which is involved in greening and spoilage of meat (Remenant et al., 2015). Taking into account these metagenomic findings, it comes as no surprise that no viable $\mathrm{LAB}$ were detected in the anaerobic culture.

Curiously, in the whiskey bottle there were also some species more characteristic for environmental samples such as Rubrivivax gelatinosus (Molisch, 1907) Willems et al., 1991, a purple nonsulfur photosynthetic bacterium found for instance in freshwater ponds and food processing wastewater (Nagashima et al., 2012). Similarly, Diaphorobacter nitroreducens Khan \& Hiraishi, 2003, a denitrifying microorganism, is also an example of bacterium that has been previously isolated from activated sludge used in wastewater treatment (Khan \& Hiairishi, 2002). Third such microorganism in our studied sample are aerobic, nitrite-oxidizing bacteria of genus Nitrospira which are abundant in various ecosystems such as wastewater treatment plants, freshwater, soils, groundwater and geothermal springs (Mehrani et al., 2020).

All in all, present analysis of microbial community in abandoned Scotch whiskey bottle based on multidisciplinary approach reveals a large spectrum of various bacterial species proliferating in it over the years, despite the high concentration of ethanol. The most numerously represented species in the sample differed in their metabolism, physiology and their usual habitat, some even being pathogenic or known food spoilers. Based on the composition of the microbial community we suppose that the contamination happened due to a direct oral ingestion, after which a part of bacterial families proliferated while the ethanol content dropped. However, after a while the growth ceased and bacteria died, but the remaining ethanol content contributed to the conservation of the nucleic acids.

\section{ACKNOWLEDGEMENTS}

The project described was supported by Omega d.o.o., Ljubljana, Slovenia.

\section{REFERENCES}

Coates, R., Moran, J., \& Horsburgh, M. J. (2014). Staphylococci: colonizers and pathogens of human skin. Future microbiology, 9(1), 75-91. https://doi.org/10.2217/fmb.13.145

Brenner J., Krieg N. R., Staley J. T. (2005). The Gammaproteobacteria. Bergey's Manual of Systematic Bacteriology. 2B (2nd ed.). New York: Springer.

Elsaghir, H., \& Reddivari, A. (2020). Bacteroides Fragilis. In StatPearls. Treasure Island (FL): StatPearls Publishing.

Karlsson, B., \& Friedman, R. (2017). Dilution of whisky - the molecular perspective. Scientific reports, 7(1), 6489. https:// doi.org/10.1038/s41598-017-06423-5

Khan, S. T., \& Hiraishi, A. (2002). Diaphorobacter nitroreducens gen nov, sp nov, a poly (3-hydroxybutyrate)-degrading denitrifying bacterium isolated from activated sludge. The Journal of general and applied microbiology, 48(6), 299-308. https://doi.org/10.2323/jgam.48.299

Laudadio, I., Fulci, V., Stronati, L., \& Carissimi, C. (2019). NextGeneration Metagenomics: Methodological Challenges and Opportunities. OMICS: A Journal of Integrative Biology. https://doi.org/10.1089/omi.2019.0073

Liu, H., Zhu, J., Hu, Q., \& Rao, X. (2016). Morganella morganii, a non-negligent opportunistic pathogen. International journal of infectious diseases: IJID: official publication of the International Society for Infectious Diseases, 50, 10-17. https://doi.org/10.1016/j.ijid.2016.07.006

Makanjuola, D. B., Tymon, A., \& Springham, D. G. (1992). Some effects of lactic acid bacteria on laboratory-scale yeast 
fermentations. Enzyme and Microbial Technology, 14(5), 350-357. https://doi.org/10.1016/0141-0229(92)90002-6

Mehrani, M. J., Sobotka, D., Kowal, P., Ciesielski, S., \& Makinia, J. (2020). The occurrence and role of Nitrospira in nitrogen removal systems. Bioresource technology, 303, 122936. https://doi.org/10.1016/j.biortech.2020.122936

Nagashima, S., Kamimura, A., Shimizu, T., Nakamura-Isaki, S., Aono, E., Sakamoto, K., ... Nagashima, K. V. (2012). Complete genome sequence of phototrophic betaproteobacterium Rubrivivax gelatinosus IL144. Journal of bacteriology, 194(13), 3541-3542. https://doi.org/10.1128/JB.00511-12

Noussair, L., Salomon, E., El Sayed, F., Duran, C., Bouchand, F., Roux, A. L., ...Dinh, A. (2019). Monomicrobial bone and joint infection due to Corynebacterium striatum: literature review and amoxicillin-rifampin combination as treatment perspective. European journal of clinical microbiology \& infectious diseases: official publication of the European Society of Clinical Microbiology, 38(7), 1269-1278. https://doi. org/10.1007/s10096-019-03542-x

O’Donovan, D., Corcoran, G. D., Lucey, B., \& Sleator, R. D. (2014). Campylobacter ureolyticus: a portrait of the pathogen. Virulence, 5(4), 498-506. https://doi.org/10.4161/ viru.28776

Paradh, A. D. (2015). Gram-negative spoilage bacteria in brewing. Brewing Microbiology, 175-194. https://doi. org/10.1016/B978-1-78242-331-7.00008-3

Quintieri, L., Fanelli, F., \& Caputo, L. (2019). Antibiotic resistant Pseudomonas spp. spoilers in fresh dairy products: An underestimated risk and the control strategies. Foods (Basel, Switzerland), 8(9), 372. https://doi.org/10.3390/ foods 8090372
Remenant, B., Jaffrès, E., Dousset, X., Pilet, M. F., \& Zagorec, M. (2015). Bacterial spoilers of food: behavior, fitness and functional properties. Food microbiology, 45(Pt A), 45-53. https://doi.org/10.1016/j.fm.2014.03.009

Simpson, K. L., Pettersson, B., \& Priest, F. G. (2001). Characterization of lactobacilli from Scotch malt whisky distilleries and description of Lactobacillus ferintoshensis sp. nov., a new species isolated from malt whisky fermentations. Microbiology (Reading, England), 147(Pt 4), 1007-1016. https://doi.org/10.1099/00221287-147-4-1007

Tessler, M., Neumann, J. S., Afshinnekoo, E., Pineda, M., Hersch, R., Velho, L., ... Brugler, M. R. (2017). Large-scale differences in microbial biodiversity discovery between $16 \mathrm{~S}$ amplicon and shotgun sequencing. Scientific reports, 7(1), 6589. https://doi.org/10.1038/s41598-017-06665-3

van Beek, S., \& Priest, F. G. (2002). Evolution of the lactic acid bacterial community during malt whisky fermentation: a polyphasic study. Applied and environmental microbiology, 68(1), 297-305. https://doi.org/10.1128/aem.68.1.297305.2002

van Beek, S., \& Priest, F. G. (2003). Bacterial diversity in Scotch whisky fermentations as revealed by denaturing gradient gel electrophoresis. Journal of the American Society of Brewing Chemists, 61(1), 10-14.

Yu, Z., Luo, Q., Xiao, L., Sun, Y., Li, R., Sun, Z., \& Li, X. (2019). Beer-spoilage characteristics of Staphylococcus xylosus newly isolated from craft beer and its potential to influence beer quality. Food Science \& Nutrition, 7(12), 3950-3957. https://doi.org/10.1002/fsn3.1256 